\title{
Significance of Literacy in Inclusive Growth and Coherent Development Planning to Deal with Challenge of Quality Education for All in Pakistan
}

\author{
Mr. Mazhar Ali Siddiqui \\ Director General Planning Development \& Research, \\ School Education \& Literacy Department, \\ Government of Sindh Karachi, Pakistan \\ Dr. Hamzo Khan Tagar \\ Director Public Private Partnership Node, \\ School Education \& Literacy Department, \\ Government of Sindh, Karachi Pakistan.
}

\begin{abstract}
The study focused on the strategic planning to achieve the sustainable development goal 4 quality education for all in context of Pakistan where more than forty percent people are illiterate and females are more than that, it examines the major obstacles in the system to improve as per need of the hour to develop innovative approach for improvement in schooling system particularly in Pakistan and generally in developing world because problems are mostly same in their nature and structure. It finds that development allocation fared poorly in the past for education development in the region, lower literacy rate strengthen feudalism and contributing to unskilled- or semiskilled labour which is spreading poverty and inequality in the country. Above all social ill also spreads negative approach like street crime terrorism, slow and unstable economic growth. Weakened Governance, Poor Quality of Teachers \& Managers needs to improve, Quality of curriculum, textbooks \& exams, out of school children, steady dropouts, In-adequate financing, Gender discrimination's, Poor monitoring \& evaluation, Imbalance in primary, middle \& secondary schools, Low Incentives and teacher's manager tussles are the major obstacles of the schooling system which impacted as low literacy and poor quality. Above mentioned issues direly need to adopt an innovative approach to tackle all obstacle's in decent manners and through coherent development planning, policies and practices within the political economy frame work due to growth and literacy nexuses in larger public interest to bring quality educations for all in Pakistan within due course of time.
\end{abstract}

Keywords: Coherent Development Planning, Literacy, Policy, Quality Education, Sustainable Development Goals (SDGs)

\section{INTRODUCTION}

The literate means "Ability to read and understand simple text in any language from a newspaper or magazine, write a simple letter and perform basic mathematical calculation (i.e. counting and addition/subtraction)" [1]. In more broad words it is the delivery of knowledge, skills and information from teachers to students and to capture what is really important in your life. Being an educated person means you have access to optimal states of mind regardless of the situation you are in.

Education is an important key to multiply the skills of people and makes them capable to participate in shaping and maintaining more sustainable economies, societies and cities, and achieve development objectives at large. Education can make a critical difference both to production patterns (e.g. with regard to the circular economy) and to consumer understanding 
of more sustainably produced goods and prevention of waste. It is a key to mass understanding of the impacts of climate change and to adaptation and mitigation. Education is important for developing awareness of the marine environment and building pro-active consensus regarding wise and sustainable use. Education and training increases skills and capacity to underpin sustainable livelihoods and conserve natural resources and biodiversity particularly in threatened environments. Life-long learning builds capacity to understand and promote sustainable development policies and practices.

The importance of Human development through literacy and learning skills to bring change in traditional societies is justified by research evidence globally and at large by the intellectual's leadership. It creates awareness to bring greater support to poor's; marginalized class, women empowerments and general awareness. Literacy have widely beneficial effects on social equality of poor masses, economic vitality for less developed and emerging economies, beneficial for entrepreneurship to organize sustainable business entity and lifting people out of vicious circle of poverty, to provide food security, improved health and hygiene, social coherence among communities and to bring political stability within weak democracies, and sustainable natural resource management in less developed countries/fragile economies.

UNESCO [2] focused on comprehensive monitoring to provide quality education for all through awareness raising, training and capacity building can help to live healthy life, protect environmental quality and lead to wiser natural and human resource use. Education plays a key role in helping people move towards more sustainable farming methods, and understanding nutrition. Education can make critical difference to a range of health issues, including early mortality, reproductive health, and spread of disease, healthy lifestyles and wellbeing. The quality education for all has great significance and a unique key to support 16 others initiatives of sustainable development agenda of united nations proposed for next 15 years including build more resilient infrastructures and more sustainable industrialization with a proven difference to social and economic inequality.

The specific objectives of the study were to:

\section{OBJECTIVES OF THE STUDY}

i. A strategic review of Pakistan's performance in school education and literacy.

ii. Assess the major obstacles in educational system of the country.

iii. Formulate coherent strategy to reach sustainable development destination in context of SDGs.

The study was guided by the following questions:

\section{RESEARCH QUESTIONS}

I. what is the current status of Pakistan's educations in terms of its level of literacy?

II. How have Pakistan tackled the different approaches to act against illiteracy?

III. What is most feasible coherent development strategy to bring innovative approach in schooling system to provide quality education for all in Pakistan?

\section{SIGNIFICANCE OF THE STUDY}

The study proposes strategies that can be used by the policy makers and implementers to improve the ratio of enrollment and quality of educations. Accordingly, the findings of the study can be used by the key players in this country to strengthen their respective roles for quality education. 


\section{METHODOLOGY\& DATA}

The qualitative / descriptive statistics strategy has been adopted to identify empirical issues. Personal observations of the author as education expert, outcome of specific and targets groups, primary and secondary data of some individuals and organizations have been used to strengthen the hypothesis. Evidences from Economic Survey of Pakistan, Secondary data of Federal Bureau of Statistics are also used.

\section{DISCUSSIONS AND RESULT}

Literacy and poverty are the major burning issues in Pakistan and not properly addressed by the elites of political economy since long both generates religious intolerances, terrorism and unskilled low quality labour force and street crime at large. Several education policy and plans were formulated and implemented in the past in Pakistan but millennium development goals plan has major focuses on literacy as its universal goal 2. Integrated approach has been adopted to address the issues of education sector development from all dimensions. The one of considerable obstacles for the poor progress in literacy was investment of the national resources against religious terrorisms in upper region and its impact on the entire country economy after 9/11/2000 tragedy.

However effective monitoring system has not been placed to assure efficiency and achievements due to political ill will and bureaucratic red-tapes. "Pakistan suffers from an extensive education crisis. Millions of Pakistani children do not attend school, and those that do must deal with absent teachers and poor learning environments, among other challenges. While this crisis is frequently discussed in Pakistan and beyond, it is often misunderstood. This new Wilson Center report, reveals that contrary to popular narratives, Pakistan's education spending has increased significantly in recent years and is now nearly equivalent to the military budget. The report argues, however, that Pakistan must spend better, not simply spend more, in order to ease and ultimately solve its education crisis. [3].

Despite of the above huddles, Pakistan has made considerable progress in reducing poverty, increase in literacy at some extent and also achieving the little gender parity targets in some cases but it needs more sincere efforts and huge investment to get rid of the manic of illiteracy from the country for sustainable inclusive growth. If we are ready to bring innovative approach for rapid and qualitative change in school's education and technical and vocational trainings area, the increase in enrolment, provision of quality teachers, reduce rate of dropout, renewed commitment to focus more on gender gap in literacy and community mobilization's is need of the hour in Pakistan which is at cross the road situation in context of literacy and growth nexus. Another important challenge is in achieving the gender parity targets in Pakistan which also correlated with increase in literacy, skills development and empowerment of the women in the feudal society of Pakistan for international competitions in literacy growth to follow the agenda of united nations in greater public interest.

The sustainable development goals targets are ambitious in terms of their universality and an extension of millennium development goals but it will be difficult to achieve without coherent development strategy. The goal 04 to address the problem of quality education for all is subject matter of this study. In our field-based experience most, educational policies and programs do not yet reflect the purposes and goals of sustainable development in local context. Spending on education in Pakistan has experienced many folds increase but still remains low in comparison of other developing countries in south Asia. Pakistan introduced several education sector reforms initiative through midterm and long-term plan but remains far from success story. Financial requirements had not been worked out properly and despite of economic and 
financial constraints provided funds are not properly utilized with broader transparency and field monitoring from nook to corner. The illiteracy and gender biased gaps are not fulfilled and literacy profile of the country is still raised serious question as progressive nation with huge human and natural resources. It is evident that integrated approach has not been adopted to address the issue of literacy and its nexuses with growth and development in Pakistan. Illiteracy is mother of all social ills and generating inequality, street crime, terrorism, languages and religious based feuds and several others problems in the society and economy. The falling Education standard, centralization of authorities at secretariat level, decreasing of Enrolment, Dilapated school buildings, missing facilities, shortage of quality teachers with their lower attendance in schools, time barred curriculum, gender and rural urban gap are the challenged areas which need to be attended on war footing basis. This sort of situation is a great hindrance in the advancement/development and improvement in public sector education. The figure given below reflects dismal picture of literacy trends with authenticated 70 years published secondary data on literacy as $58 \%$ in digital era of 21 th century. The total progress/ increase in overall from $17.9 \%$ to 58 rural and gender disparities are also shows dismal pictures in literacy's over all $48 \%$ and in rural area female literacy is less than $36 \%$ in the country as shown in figure 1.

Figure 1. Census Wise Evidences of Literacy in Pakistan

\begin{tabular}{|l|l|l|l|l|l|l|l|}
\hline $\begin{array}{c}\text { Year } \\
\text { of } \\
\text { census }\end{array}$ & Total & Male & Female & Urban & Rural & Who is Literate? & $\begin{array}{l}\text { Age } \\
\text { group }\end{array}$ \\
\hline 1951 & $\mathbf{1 7 . 9 \%}$ & $21.4 \%$ & $13.9 \%$ & N/A & N/A & $\begin{array}{l}\text { One who can read a clear } \\
\text { print in any language }\end{array}$ & All Ages \\
\hline 1961 & $\mathbf{1 6 . 9 \%}$ & $26.1 \%$ & $6.7 \%$ & $34.8 \%$ & $10.6 \%$ & $\begin{array}{l}\text { One who is able to read with } \\
\text { understanding a simple letter in any } \\
\text { language }\end{array}$ & $\begin{array}{l}\text { Age } 5 \\
\text { and } \\
\text { above }\end{array}$ \\
\hline 1972 & $\mathbf{2 1 . 7 \%}$ & $30.2 \%$ & $11.6 \%$ & $41.5 \%$ & $14.3 \%$ & $\begin{array}{l}\text { One who is able to read and } \\
\text { write in some language with } \\
\text { understanding }\end{array}$ & $\begin{array}{l}\text { Age } 10 \\
\text { and } \\
\text { Above }\end{array}$ \\
\hline 1981 & $\mathbf{2 6 . 2 \%}$ & $35.1 \%$ & $16.0 \%$ & $47.1 \%$ & $17.3 \%$ & $\begin{array}{l}\text { One who can read newspaper } \\
\text { and write a simple letter }\end{array}$ & $\begin{array}{l}\text { Age 10 } \\
\text { and } \\
\text { Above }\end{array}$ \\
\hline 1998 & $\mathbf{4 3 . 9 2 \%}$ & $54.81 \%$ & $32.02 \%$ & $63.08 \%$ & $33.64 \%$ & $\begin{array}{l}\text { One who can read a newspaper } \\
\text { and write a simple letter, in any } \\
\text { language }\end{array}$ & $\begin{array}{l}\text { Age 10 } \\
\text { and } \\
\text { Above }\end{array}$ \\
\hline 2017 & $\mathbf{5 8 \%}$ & $70 \%$ & $48 \%$ & $63 \%$ & $36 \%$ & $\begin{array}{l}\text { Ability to read and understand simple } \\
\text { text in any language from a newspaper } \\
\text { or magazine, write a simple letter and } \\
\text { perform basic mathematical } \\
\text { calculation (ie, counting and } \\
\text { addition/subtraction) }\end{array}$ & $\begin{array}{l}\text { Age 15 } \\
\text { and } \\
\text { Above }\end{array}$ \\
\hline
\end{tabular}

Source:

[1] Economic Survey of Pakistan various issues.

[4] Wikipedia Encyclopedia: Web Page Service.

\section{COHERENT DEVELOPMENT PLANNING TO REACH THE DESTINATION OF QUALITY EDUCATION FOR ALL}

The Government of Pakistan has promulgated compulsory education ordinance in 2013 and publicly announced to impose an emergency for elevating the standard of Education specially to bring changes in the area of School Education in the global context. Moreover, our country has signed Sustainable Development Goals (SDGs), a 17 points international development agenda as framed by UNO also signed by 193 countries in September 2015 to fulfill the 
objectives in the local context to increase literacy of masses with implementation of goal 4 quality education for all. Actually, the Emergency is an action that is done or arranged quickly and not in the normal way. After declarations of emergency no concrete initiatives has been taken to move forward to achieve the goal through educational emergency. For the amelioration of public in general and to cope up with this situation we need to adopt following steps with harmonious interaction, consultation and concomitant coordination with activation of established institutions in shortest possible time as coherent development planning/ strategy to implement "Compulsory Education Act 2013", into the reality and also to implement international agenda of (SDGs) goal 04 quality education for all in next 15 years. This proposed plan and points to ponder below towards concrete initiatives on subject matter will strengthen Government's efforts to impart compulsory and free quality education to each and every child of the country as objected. The World Bank's core strategy also calls for: "Investing early, because the foundational skills acquired early in childhood make possible a lifetime of learning and Investing smartly, because investments that prioritize learning and skills development-and their measurement, to inform reform-are most effective in producing results and also focused Investing for all, targeting girls and disadvantaged populations, because a nation can prosper only when all children enjoy an opportunity to learn" [5].

\section{Academic Initiatives Needed in the Coherent Education Development Strategy}

Human factor in education needs greater policy attention to change the mindset of policy makers first to produce quality education for prosper future of the nation and second to focus on professionals for speedy progress rather than time barred bureaucrats. Educational Leadership should be promoted in the system through carefully designed professional development centers with incentives in the same line of executive class of the country. More emphasis should be placed to increase in the number of training and education institutions for teachers and trainers; increase in the number of youth-led initiatives on education sector development; and increase in the number of local educational sector development initiatives. At the improvement in quality of education teachers should have required academic and professional qualifications with passions. Student teacher ratio may be increased at primary level but more focused at secondary level Science English and Math's teachers as per global standard.

\section{Curriculum and Examination System and Professional Development Centers}

The assessment and examination system should be reviewed for structural changes because its time barred in this modern era. School Education Standards and curriculum is also old and on traditional pattern and needs structural improvement to bring quality educations in government schools. The government and private sector experts may undertake the joint responsibility to provide maintenance of school education standards, reflecting the needs of 21st century, through supervision of research-based curriculum, textbook and other related learning material, assessment, and evaluation. to develop quality and standard of teaching material in global context. Teaching materials can support student learning and increase student success in improved examinations system at large. Revisiting teacher education programs and establishment of professional development center in each district to serve as resource hub for school's improvement and coupe with privet sector school is very essentials. Sustainable improvement in school effectiveness and the quality of education is only possible when apex institutions act with sufficient professionals to support top management through research on educational issues with their sustainable solutions. 


\section{More Emphasis on Early Child Education}

In Pakistan Early Child Education stage has been recognized as part of formal education structure and curriculum has been designed to organize pre-primary education. The gross participation of ECE children has substantially increased literacy in the region. In these school females of same village may be preferred to deliver in context of kind and care of enrolled child and gender promotions at gross rots level. Policy should be formulated and implemented to recruit only female teachers for primary schools which obviously will help to increase the female enrolment. Situation will be in favour of females such as survival rates to grade $\mathrm{V}$, transition rate between primary and lower secondary as well as between lower secondary to upper secondary. The introduction of early child education in public sector will also cope with private sector in their monopolistic role in the country.

\section{Robust Infrastructural Development Policy}

A nationwide Program has been launched to address the missing facilities in schools such as drinking water, electricity, toilets and boundary walls because only toilet facilities in girl's school can be increase above $10 \%$ of enrollment in Pakistan. The results of the efforts of infrastructural reforms are not encouraging which reflect its poor commitment to attain the targets of quality education for all as reflected dismal picture. Partnerships in infrastructure with private sectors will be more feasible in comparison of partnership in management. Social Investment Bonds for infrastructure development in the schools will be breakthrough in the sector its succeed lesson in South Korea, America and others developed countries is an example. It is also need of the time coupe the challenge of infrastructural development with big push concept and taken the issue in midterm plan.

\section{Low Cost Public Private Partnerships Model}

The PPP model of education in the region has much significant to deliver among unnerved communities and can be accommodate more than 22 Million out of school's children. It can be planned that larger communities managed schools can be operate by enhancing Rs.3000 per child per month subsidy-based model. Rupees one thousand for school entrepreneurs and 1000 thousand for enrolled child will defiantly be attractive to bring the street children/child labour in schools. Remaining 1000 rupees should be comprising students' text books, copies, students' school bags \& material cost. It is also evident many thousands closed/defunct schools caused embracement of the government's efforts and buildings are empty or in abundant conditions these may be repaired with cooperation's of communities and private sector and can be used for litrecy growth in context of our global agenda quality education for all as objected in sustainable development goal 04 by the united nations.

\section{Governance Improvement Strategy at National Level}

The government of Pakistan initiated different plans/strategies 'to create a knowledge-based society for accelerating on-going growth and development process for prospers future of the tomorrow people by arranging possible resources for capacity building of the managers, researchers \& development professionals, for provision of education access to lower class children to decreased disparity and to increase the quality of education for all but above referred plan are still encandle to flame the real sprit in implementation at the field and reduction of regional and gender disparity in educational sector is not properly address and improved in past plans. So that development of plans, projects and strategies are needed a comprehensive implementation strategy to improve access, equity and quality of the basic education and literacy with participatory approach without political ill wills and bureaucratic hurdles we mean rad tapes here. 


\section{Local Level Strategy to Cope the Challenge of Lower Rate of Literacy}

District Managers may be placed on merit through panel interviews and to be made responsible of their respective District to take up the matter with quiet help of the local community elders, politicians and Department top management. Besides they must furnish information of poor infrastructure missing facilities and the progress of under construction schools. The District managers may be bound to remain in the field and ensure the attendance of teachers through their subordinate offices. Schools Specific Budget is not properly utilized since last many decades because; a number of managerial positions are vacant and needs to be filled and activate on urgent basis for sustainable service delivery.

\section{Strengthen of Educational Policy Commission}

The rapid change in education sector needs greater policy attention of the planners within the framework of political economy of public policies. National and Provincials Education Policy Commissions may be re- established and activated and to assigned the task to take concerts initiatives regarding implementation of the proposed strategy within due course of time Separate entity maybe established within the department in long run to implement compulsory education act in letter and sprit and all others required steps and actions proposed in the coherent strategy.

Vocational and technical institutions and their quality should be focused in policymaking because Pakistan is the second top in the globe with equipped by young populations but its dilemma that majority of youth are illiterate unskilled or semi-skilled. The available policy commission are dysfunctional in nature and scope even they haven't play significant role in school's improvement's these may be reorganized and re-strengthen as per need of the hour and in global agenda of united nations for inclusive growth strategy.

\section{Field Based Monitoring Strategy}

At Global level Paris based UNESCO is a monitoring agency which has already taken the responsibility to monitor progress in implementing goal 04 targets in overall the world.in context of above independent agencies may be hired to keep eagle eye on the initiative's and like Malaysia and Singapore Deputy Prime Minister position may be created in power corridors to oversee the progress of universal goal thorough high-level empirical monitoring. The development partners in education sector of Pakistan need to honor their commitment and to provide aid / grant with transformation of experiences of developed society and not only a loan for a noble cause and also provide capacity building support for field-based monitoring with modern tools.

\section{Data Collection Strategy}

District Education Managements Information System offices may be activated with modern tools and equipment's to serve on-line as these units have not encandle any flame from its establishment since 1990 resultantly authenticity of data becomes a question mark and leads the failure of all initiatives. District Based data center are established but are not activated because teachers are wondering from pillar to post for their biometric and related issues resultantly they do not pay attention but biometric issues. So, decentralization of authorities at district level is need of the hour to collect the valid data for sustainable development planning within the education sector to re-address the challenges in decent manners. The capacity of data collection institutions may be reviewed as in present scenario they are not result oriented and up to the required quality standard. 


\section{Community Awareness, Mobilization and Participation in Educational Development}

Sustainable improvement in literacy, school effectiveness and the quality of education is only possible when apex institutions with sufficient professionals and capacity provide support to top management through research on educational issues with their sustainable solutions with cooperation of communities at gross roots level. Though School Management Committees and parent teachers' associations have working but the organizational form of these bodies in most cases is not proving effective. It would be useful to review the organizational framework of community awareness, mobilization and participation which has to be more flexible and less prescriptive in nature. Reaching to the out-reach and disadvantage groups, enhancing the transitional and survival rates and minimizing the dropout and repetition rates needs community awareness and participation in public sector schools at large.

\section{CONCLUSION}

The qualitative analysis concludes that scarce allocation and its time barred utilizations system with massive mismanagement affected referred agenda of human development. The study finds that development allocation fared poorly in the past for education development in the region, low literacy rate strengthen feudalism and encourage corruption, contributing to unskilled- or semi-skilled labour, poverty and inequality in the country. The more spending on education do not bring candle light as well as spending more efficiently is dire need of the country. However effective monitoring system has to be in place to assure efficiency and achievements of the yearly investment of public sector spending. Country introduced education sector reforms with collaboration of international donors' organization's and nation plan of action but lack of comprehensive strategy for implementations is major obstacles. Capacity of educational managers should be enhanced with market-based incentive's and freedom to act freely beyond control of the red tapes. There is need to adopt coherent development planning practices already adapted by developed world for quality education and vocational training to produce and supply skilled labour to serve globally with decent manners. At public policy level huge investment in area of producing quality teachers with cooperation of Private sectors on public private partnership modality, capable managers trained by public policy institutions for decent management practices in schools and for sustainable infrastructural improvements are desired as a big push strategy to reach the destination of quality education for all in the country.

\section{References}

Pakistan Government of (2016), Economic Survey of Pakistan. Islamabad, Ministry of Finance \& Economic Affairs Division. pp. 23.

UNESCO. (2014). Teaching and learning: Achieving quality for all. Education for All (EFA) Global Monitoring Report 2013/4.United Nations. (n.d.).

Nadia Naveen 2016 "Pakistan's Education Crisis: The Real Story” Woodrow Wilson International Center for Scholars One Woodrow Wilson Plaza 1300 Pennsylvania Avenue NW Washington, D.C. 20004-

3027.www.wilsoncenter.org.

Wikipedia Encyclopedia Web Page Service: https://en.wikipedia.org/wiki/Education_in_Pakistan

World Bank (2011) Education Sector Strategy 2020: Learning for All: Investing in People's Knowledge and Skills to Promote Development Washington, DC. 